Orientalia Christiana Cracoviensia 8 (2016), s. 115-126

DOI: http://dx.doi.org/10.15633/ochc.2200

Sławomir Cebula

Uniwersytet Papieski Jana Pawła II w Krakowie

\title{
Tatarzy z Bohonik i Kruszynian. Tożsamość, asymilacja, współczesne wyzwania
}

\begin{abstract}
The Tatars from Bohoniki and Kruszyniany. Identity, assimilation, contemporary challenges. Tartars who settled in Bohoniki and Kruszyniany underwent a long process of assimilation, still preserving some features of the culture of their ancestors and absorbing many elements of the local culture. Centuries-old military traditions deepened their bond with Poland, which is the only motherland for them. During research conducted in 2015 questions were renewed as to their ethnic identity, whose main elements are Islam and mutual origin. The researchers focused also on contemporary problems that Tartarian community had to face. At the same time, the article points out characteristic and unique features of Tartarian Islam permeated by local influences.

Tatarzy z Bohonik i Kruszynian. Tożsamość, asymilacja, współczesne wyzwania. Tatarzy osiedleni w Bohonikach i Kruszynianach przeszli długi proces asymilacji, zachowując pewne cechy kultury swych przodków i przyswajając wiele elementów kultury miejscowej. Wielowiekowe tradycje wojskowe pogłębiły ich więź z Polską, która jest dla nich jedyną ojczyzną. Podczas badań przeprowadzonych w 2015 roku zostały postawione na nowo pytania o ich tożsamość etniczną, której kluczowymi elementami są wyznawany islam oraz wspólne pochodzenie. Skupiono się również na aktualnych problemach, z jakimi musiała zmierzyć się społeczność tatarska. Artykuł wskazuje równocześnie na charakterystyczne i unikatowe cechy tatarskiego islamu, przesiąkniętego wpływami lokalnymi.
\end{abstract}

Keywords Tartars, ethnic identity, assimilation, religious minorities, ethnic group, interdenominational dialogue

Tatarzy, tożsamość etniczna, asymilacja, mniejszości wyznaniowe, grupa etniczna, dialog międzywyznaniowy 
Postępujący przez wieki proces asymilacji polskich Tatarów żyjących w północno-wschodniej części kraju sprawił, że wytworzyli i utrwalili oni własne, unikatowe modele interakcji transkulturowej. Wpłynęło to znacząco także na ich tożsamość etniczną ${ }^{1}$. Gdy z czasem zacierało się wiele spośród elementów kultury ich przodków, czerpano z kultury miejscowej. Tożsamość kształtowana w tyglu kulturowym może wykazywać zarówno cechy separatystyczne, jak i dyfuzjonistyczne, kształtując różnorodne formy synkretyczne, a w niektórych przypadkach może nawet dojść do jej utraty czy ściślejwyparcia poprzez całkowite zdominowanie przez inną kulturę. Co zatem można powiedzieć o tożsamości dzisiejszych polskich Tatarów?

Popularne przez dekady sformułowanie, że „każdy Tatar w Polsce to muzułmanin i każdy muzułmanin w Polsce to Tatar" nie opisuje już dzisiejszej rzeczywistości i należy zaliczyć je do powiedzeń historycznych. Napływ wyznawców islamu z krajów arabskich, zrzeszających się przede wszystkim w Lidze Muzułmańskiej w RP, jeszcze w poprzednim stuleciu definitywne zdezaktualizował drugi człon powiedzenia, pierwszy zaś podważają coraz popularniejsze związki mieszane wyznaniowo, które zawierają polscy Tatarzy. Sprawiają one, że potomkowie Tatarów nie zawsze wychowywani są jako wyznawcy islamu.

Asymilacja zdaje się przybierać obecnie nowy wymiar, w myśl zasady, że każde czasy mają swoje wyzwania. Jakie znaczenie ma fakt, że islam przestaje tak wyraźnie stanowić o odrębności grupy? Dynamika postępujących zmian sprawia, że warto postawić jeszcze raz pytanie o przeobrażenia struktury tożsamości polskich Tatarów. Czy idą one w kierunku coraz większego eksponowania elementów tradycji tatarskiej? A może Tatarzy powoli integrują się z pozostałymi polskimi muzułmanami w imię „oczyszczania” wiary z naleciałości zwyczajów stricte tatarskich, co doprowadzi do zepchnięcia elementów ich tradycji na dalszy plan?

Celem mojego artykułu jest analiza wyników badań przeprowadzonych na przełomie kwietnia i maja 2015 roku w Bohonikach i Kruszynianach²,

1 Niektórzy badacze odmawiali Tatrom miana grupy etnicznej, określając ich jako grupę etnograficzną. Por. J. Talko-Hryncewicz, Muślimowie, czyli tak zwani Tatarzy litewscy, Kraków 1924. Autor niniejszego artykułu przychyla się jednak do tych, którzy uznają Tatarów za grupę etniczną. Por. K. Warmińska, Tatarzy polscy - tożsamość religijna i etniczna, Kraków 1999; J. Kamocki, Tatarzy polscy jako grupa etnograficzna, „Rocznik Tatarów Polskich” 1 (1993), s. $43-47$.

2 W badaniach obok autora artykułu udział wzięli dr Piotr Czarnecki oraz Anna Kaim, Filip Kinczyk, Karolina Kogut, Paweł Komorowski, Joanna Słonka, Anna Symber, Katarzyna Szlęk i Justyna Wątroba. 
dwóch najważniejszych historycznie enklawach tatarskich w Polsce, gdzie mieszka niemal 1/3 polskich Tatarów. Przedmiotem owych badań było ponowne określenie tożsamości etnicznej Tatarów polskich połączone $\mathrm{z}$ analizą procesu asymilacji oraz stosunku do wybranych współczesnych problemów, jak ubój rytualny, fala imigrantów z Bliskiego Wschodu czy ekspansja tzw. Państwa Islamskiego.

\section{Tożsamość etniczna polskich Tatarów}

Tożsamość etniczna opiera się na poczuciu wspólnoty grupowej i wzmocniona jest więzami zamieszkania, pokrewieństwa, języka, religii, wspólnej historii i przodków oraz obyczajów czy tradycji³ ${ }^{3}$. Jak zostało to już wykazane we wcześniejszych badaniach (m.in. prof. Katarzyny Warmińskiej z połowy lat dziewięćdziesiątych XX wieku) ${ }^{4}$, tożsamość społeczności tatarskiej opierała się na dwóch głównych filarach: islamie oraz świadomości wspólnego pochodzenia etnicznego. Przeprowadzone dwadzieścia lat później wywiady potwierdzają ten stan rzeczy. Islam to wciąż ważny element tożsamości. $\mathrm{Na}$ uwagę zasługuje tu jednak jego tatarska specyfika, czyli nacechowanie zarówno wpływami chrześcijańskimi, jak i śladami dawnych zwyczajów mających swe źródło w okresie przedislamskim, z szamanistycznym wróżbiarstwem, które zachowało się do dnia dzisiejszego np. w dobieraniu szczęśliwych dni do zawarcia związku małżeńskiego. Inną charakterystyczną cechą islamu tatarskiego, nabytą z pewnością po zmianie trybu życia na osiadły i zaczerpniętą z chrześcijaństwa oraz mającą swe podstawy w tradycji pielęgnowania pamięci o przodkach jest to, że Tatarzy w odróżnieniu od innych wyznawców islamu chętniej dbają o groby bliskich, nie obawiając się przebywania dłużej na mizarze, traktowanym częstokroć w islamie jako miejsce nieczyste.

Nie bez znaczenia dla charakteru tatarskiej religijności pozostaje również to, że społeczność ta funkcjonowanie jako mniejszość, co utrwaliło np. powszechne nieprzestrzeganie pięciokrotnej modlitwy w ciągu dnia (salat), lecz przekładanie jej na jeden dzień, kiedy odmawiana jest kumulatywnie za cały tydzień. Jest to niewątpliwie wyraz dopasowania się do zastanych form za-

3 Por. P. Sztompka, Socjologia, Kraków 2004, s. 256, 585, 599; K. Warmińska, Islam a etniczność na przykładzie Tatarów polskich, w: Miscellanea islamica. Islam w badaniach i praktyce kontaktów międzykulturowych, red. P. Stawiński, Kraków 2016, s. 123-144.

4 Por. K. Warmińska, Religijność a dylematy tożsamości-Tatarzy polscy, w: Między Wschodem a Zachodem, red. P. Stawiński, Częstochowa 1995, s. 47. 
chowań społecznych. Z kolei pielgrzymka do Mekki (hadżḋ) jest uwarunkowana względami finansowymi i zdrowotnymi. Pozostałe filary wiary są przeważnie przestrzegane. Podkreślane jest rygorystyczne wypełnianie postu w miesiącu ramadan, co jest szczególnie uciążliwe w miesiącach letnich, kiedy dzień jest bardzo długi. Tatarskie meczety w Bohonikach i Kruszynianach nie posiadają minaretów, skąd by muezin nawoływał ich na modlitwę, architektonicznie przypominają raczej wiejskie drewniane kościółki, co jest kolejnym z wyrazów asymilacji.

Religijność Tatarów przesiąknięta jest obyczajowością przodków, przejawia pewne tendencje asymilacyjne, o czym świadczy choćby wspomniana wyżej praktyka przekładania modlitw na jeden dzień tygodnia. Można jednak wyznaczyć granicę akceptowalnej asymilacji - stanowią ją przypadki odejścia od islamu w wyniku zawarcia małżeństwa z osobą innej religii. Starsze pokolenie ocenia ten fakt raczej negatywnie, stojąc na stanowisku endogamii i nie wyrażając entuzjazmu wobec małżeństw mieszanych.

Z kolei świadomość wspólnego pochodzenia, jako drugi kluczowy element tożsamości grupy, jest powszechna, lecz - co istotne - nie opiera się na pielęgnowanej przez wieki pamięci historycznej, języku czy mitach. Na ich zagubienie na przestrzeni wieków wpłynął koczowniczy tryb życia Tatarów. Bardziej pielęgnowany jest etos Tatara jako doskonałego żołnierza, służącego dzielnie i nieszczędzącego w razie potrzeby życia dla obrony swej ojczyzny - Polski. Do dziś w relacjach mocno akcentowane są cnoty wojskowe, takie jak: odwaga, waleczność, honor czy wierność. Wydarzenia historyczne, w których Tatarzy odgrywali znaczącą rolę w dziejach Rzeczypospolitej, przechowywane są pieczołowicie w pamięci zbiorowej.

Ważny element tożsamości etnicznej i kulturowej, jakim jest język, u Tatarów ma marginalne znaczenie. Język tatarski zanikł jeszcze w XVII stuleciu, gdy pozwolono żołnierzom tatarskim osiedlać się na ziemiach polskich i żenić z miejscowymi kobietami, które z kolei mówiły do swych dzieci we własnym (polskim, czasem białoruskim) języku5. Mimo odejścia w zapomnienie języka polskich tatarów, wiele spośród funkcjonujących do dziś w języku polskim słów ma rodowód tatarski. Należą do nich np.: ułan, buława, kaftan, atłas, basza, arbuz, kobierzec, opończa, orkisz, dzida czy taśma ${ }^{6}$.

5 Por. J. Kulwicka-Kamińska, I. Kamiński, Islam po polsku, Poznań 2007, s. 113-119; Polscy muzułmanie - rozmowa z Barbara Pawlic-Miśkiewicz przeprowadzona przez Tomka Kaczora i Jana Wiśniewskiego, „Kontakt” 2016 nr 31, s. 98.

6 Por. K. Cicha, Urwana nuta, ,Kontakt” 2016 nr 31, s. 104. 
Dziś społeczność tatarska próbuje poznać język przodków, chociaż nadal nie można mówić o jego realnym znaczeniu w życiu codziennym. Kolejnym wyzwaniem stała się próba odtworzenia lub właściwie stworzenia na nowo zupełnie zapomnianej muzyki tradycyjnej. Zadanie to Tatarzy powierzyli Karolinie Cichej i Bartowi Pałydze, osobie nieprzynależącej do ich grupy etnicznej, ale związanej z Podlasiem. Tworzone w ten sposób pieśni będą opierały się zarówno na utworach Tatarów nadwołżańskich, jak i krymskich, zaś języki powstającej ,,antologii muzyki dla Tatarów polskich” to kazański, krymski i polski. Celem autorki jest wprowadzenie do kanonu pieśni jak najbardziej zbliżonych do zapomnianej muzyki tatarskiej, również z odtworzeniem oryginalnego instrumentarium ludów stepowych ${ }^{7}$.

Podczas przeprowadzanych badań Tatarzy niejednokrotnie wyrażali swoje przywiązanie do Polski, podkreślając, że jest to ich jedyna ojczyzna. Typowymi wypowiedziami na ten temat były:

- ,jesteśmy Polakami”;

- „kultura arabska jest nam obca, bliska polska”;

- ,jesteśmy Polakami tatarskiego pochodzenia”;

- „my też jesteśmy Polakami [...] i nie mamy żadnej ojczyzny poza Polską".

Odwiedzający Bohoniki i Kruszyniany turyści, nie znając wielowiekowego przywiązania Tatarów do swojej ojczyzny, pytają ich niekiedy, czy czują się oni Polakami. Na tak postawione pytanie Tatarzy zwykli odpowiadać „my Polakami się nie czujemy - my Polakami jesteśmy”8.

\section{Asymilacja}

Sygnalizowanemu już wcześniej procesowi asymilacji warto poświęcić nieco więcej uwagi. W odniesieniu do społeczności polskich Tatarów następuje on w sposób ciągły, od czasu osiedlenia się na ziemiach polskich aż po dzień dzisiejszy. Tatarów, jak już wspomniano, łączy islam i wspólne pochodzenie. Jednakże poprzez wielowiekowe współegzystowanie z narodem o innej wierze i kulturze, zatracili oni wiele pierwotnych cech o charakterze kulturowym,

7 Por. K. Cicha, Urwana nuta, dz. cyt., s. 102-105.

8 Większość cytowanych wypowiedzi została zarejestrowana przez autora artykułu podczas badań terenowych w dniach od 30 kwietnia do 3 maja 2015 roku we wisach Bohoniki i Kruszyniany. Materiały w posiadaniu autora artykułu: Archiwum Sławomira Cebuli [dalej: ASC], Badania terenowe. Bohoniki-Kruszyniany, 30.04-03.05.2015, mat. nr 1 . 
przyjmując na ich miejsce nowe. Niewątpliwie czynnikiem wzmacniającym asymilację jest fakt, że w odróżnieniu od wielu innych mniejszości, Tatarzy nie mają jakiejś pozostawionej ojczyzny. Jak stwierdziła Barbara Pawlic-Miśkiewicz: „Jesteśmy wyjątkową mniejszością etniczną, bo nie mamy poza Polską żadnego miejsca, z którym moglibyśmy się identyfikować. Białorusini czy Litwini mają swoją ojczyznę, a do tego jasno zdefiniowany język, pochodzenie. Tatarzy mają tylko religię" " Ów fakt nieposiadania opuszczonej ojczyzny, wzmacnia więź z Polską jako jedyną ojczyzną.

Bezspornie należy stwierdzić, że na szczeblu lokalnym stopień asymilacji jest pełny. Tatarzy zżyli się ze swoimi sąsiadami. Nie sprawdzają się tu modele postawy dystansu wobec innych wyznań. Katoliccy i prawosławni mieszkańcy Kruszynian, Bohonik oraz okolicznych wsi traktują Tatarów jako „swoich”"10. Znajduje to potwierdzenie w wielu zarejestrowanych wypowiedziach typu: „żyjemy w zgodzie z katolikami i prawosławnymi, nie ma konfliktów". Stan ten zresztą potwierdzają przedstawiciele wszystkich religii.

Jednakże asymilacja nie kończy się tu na wzajemnej akceptacji i poprawnym współżyciu. Tatarzy, prawosławni i katolicy zapraszają się nawzajem na święta religijne, a w przypadku rodzin mieszanych wyznaniowo obchodzą często wspólnie święta obu religii. Mamy tu zatem do czynienia z najdoskonalszą formą dialogu międzyreligijnego, bo nacechowaną autentycznym, codziennym i naturalnym kontaktem pomiędzy wyznaniami. Rozmawiając z mieszkańcami Bohonik i Kruszynian, można dojść do wniosku, że odmienności w wyznawanych religiach nie dzielą, lecz sprawiają, że tworzą oni różnorodną całość. Dialog międzyreligijny przybiera tu również bardziej oficjalne formy w postaci wspólnej modlitwy o pokój czy modlitwy pięciu kultur, na które przybywają goście z zewnątrz. Muzułmanie z Bohonik i Kruszynian przechowują w pamięci również spotkanie z papieżem Janem Pawłem II, wyrażając się o nim z dużym szacunkiem. Podczas prowadzonych rozmów pokazano nam fotografie $\mathrm{z}$ tego spotkania.

Najważniejszą obserwowaną zmianą w stosunku do wcześniejszych badań jest wzrost akceptacji związków mieszanych, które do lat osiemdziesiątych XX wieku były przez społeczność tatarską silnie piętnowane ${ }^{11}$. Starsze

9 Polscy muzutmanie - rozmowa z Barbarą Pawlic-Miśkiewicz..., dz. cyt., s. 98.

10 Por. E. Nowicka, Dystans polskich katolików wobec innych wyznań, w: Religia a obcość, red. E. Nowicka, Kraków 1991, s. 26-55.

11 Por. Polscy muzutmanie - rozmowa z Barbara Pawlic-Miśkiewicz..., dz. cyt., s. 99; K. Warmińska, Religijność a dylematy tożsamości - Tatarzy polscy, dz. cyt., s. 47-54. 
pokolenie zdecydowanie stoi po stronie endogamii ${ }^{12}$, przez co wywołuje presję na młodym pokoleniu. Zapewne $\mathrm{z}$ tego powodu w wypowiedziach dotyczących tej kwestii spotkać można było najwięcej rozbieżności: od akceptacji („mam zięcia Araba [...], dwóch zięciów katolików nie jest gorszych niż Arab"), poprzez neutralne opisy sytuacji pozbawione komentarza (jest „dużo związków mieszanych”), aż po pogodzenie się z zaistniałą trudną sytuacją, nacechowane równocześnie troską o konsekwencje asymilacji wynikającej z częstych małżeństw mieszanych (,asymilacja jest duża, jeden ożenił się z Tatarką, drugi z katoliczką, wnuczka jest ochrzczona, my nie robimy z tego problemu, ale sytuacja jest jaka jest”; ,asymilacja będzie nadal trwała i to jest nieuniknione").

Ostatnia z zacytowanych powyżej wypowiedzi zdaje się dotykać problemu granic akceptowanej asymilacji. Zawieranie małżeństw mieszanych może się bowiem przyczynić do zaniechania praktyk religijnych, oddzielania od jednego z najważniejszych elementów tożsamości polskich Tatarów - islamu, co z kolei może wpływać na zmniejszanie się liczebności grupy. Pewnym krokiem mającym na celu jeszcze większe skonsolidowanie tej społeczności, obok utrwalonej tradycji wspólnego świętowania najważniejszych świąt, jest budowa Centrum Edukacji i Kultury Muzułmańskiej Tatarów Polskich w Kruszynianach. Centrum ma dodatkowo utrwalić całe bogactwo dziedzictwa kulturowego polskich muzułmanów - mają do niego trafić, jako eksponaty, liczne, cenne pamiątki historyczne przechowywane w domach.

Odpowiedź na pytanie, czy rzeczywiście mniejszości z 600-letnią tradycją grozi stopniowy zanik teoretycznie można byłoby znaleźć w danych Głównego Urzędu Statystycznego (GUS). Według nich liczba członków Muzułmańskiego Związku Religijnego w RP (MZR) w ostatnich czterech latach spadła prawie o połowę.

Tabela 1. Liczba członków Muzułmańskiego Związku Religijnego w RP na podstawie danych GUS

\begin{tabular}{|c|c|}
\hline Rok & Członkowie \\
\hline 2010 & 1061 \\
\hline 2013 & 826 \\
\hline 2014 & 585 \\
\hline
\end{tabular}

Źródło: P. Ciecieląg, Wyznania religijne w Polsce 2012-2014, Warszawa 2016, s. 143-144.

12 Por. M. Łyszczarz, Młode pokolenia polskich Tatarów, Olsztyn-Białystok 2013, s. 137-143. 
Na marginesie można dodać, że rozkład terytorialny skupisk Tatarów w Polsce przedstawiał się w 2014 roku następująco: Białystok (137 osób), Warszawa (125 osób), Bohoniki (109 osób), Gdańsk (94 osoby), Kruszyniany (60 osób), Podlodów (60 osób) ${ }^{13}$. Jeśli uznać te wyniki za miarodajne, to na Podlasiu wciąż mieszka ponad połowa polskich Tatarów.

Jednakże do powyższych danych należy podchodzić z ostrożnością, gdyż inne tabele GUS, prezentujące wyniki Narodowego Spisu Powszechnego Ludności z 2011 roku określają liczbę Tatarów w Polsce (ze względu na przynależność etniczną, bez brania pod uwagę przynależności do MZR) na $1916^{14}$. Nie można mieć pewności, że rozbieżność w liczbie Tatarów w narodowym spisie powszechnym i liczbie członków MZR wynika z konwersji.

Oprócz MZR, skupiającego społeczność tatarską wyznającą islam notuje się niezwykle dynamiczny wzrost liczby członków Ligi Muzułmańskiej w RP, skupiającej wyznawców islamu pochodzących z krajów arabskich: 208 członków w 2006 roku, 1500 członków w 2007 roku i 3800 członków w 2010 roku $^{15}$. Wpływa to również na zwiększenie częstotliwości kontaktów pomiędzy Tatarami a innymi wyznawcami islamu w Polsce. Efekty asymilacji są niekiedy szokujące dla arabskich muzułmanów, gdy widzą, że „młode dziewczęta, które [...] są już po okresie dojrzewania, nie zasłaniają się; że nastolatki chodzą na dyskoteki, tak jak ich szkolni rówieśnicy; że niektórzy mężczyźni nie stronią od alkoholu"16. Reakcją na kontakty $\mathrm{z}$ innymi wyznawcami islamu stał się nurt powrotu do ortodoksji propagowany przez marginalną część młodego pokolenia Tatarów ${ }^{17}$. Dla większości zarówno starszego, jak i młodszego pokolenia kultura arabska, w odróżnieniu od polskiej jest obca, a wcześniejsze dobre relacje muzułmanami przybywającymi do Polski zaczęły się pogarszać po ich zrzeszeniu w Lidze Muzułmańskiej w 2004 roku. Liga Muzułmańska stała się konkurencją dla Muzułmańskiego związku religijnego ${ }^{18}$.

13 Por. P. Ciecieląg, Wyznania religijne w Polsce 2012-2014, dz. cyt., s. 143.

14 Por. Główny Urząd Statystyczny, Ludność. Stan i struktura demograficzno-społeczna. Narodowy Spis Powszechny Ludności i Mieszkań 2011, Warszawa 2013, s. 262.

15 Por. Główny Urząd Statystyczny, Ludność. Stan i struktura ..., dz. cyt., s. 146.

16 Polscy muzutmanie - rozmowa z Barbara Pawlic-Miśkiewicz..., dz. cyt., s. 99.

17 Por. Polscy muzutmanie - rozmowa z Barbarą Pawlic-Miśkiewicz..., dz. cyt., s. 100.

18 Por. M. Łyszczarz, Młode pokolenia polskich Tatarów, dz. cyt., s. 146. 
Mimo że prowadzone w Bohonikach i Kruszynianach badania koncentrowały się na problemach tożsamości i asymilacji, zadane zostały również pytania dotyczące wybranych, aktualnych problemów, tj.: uboju rytualnego, tzw. Państwa Islamskiego i fali imigrantów.

Tatarzy od wielu wieków podczas święta ofiarowania Kurban Bajram dokonywali uboju rytualnego ${ }^{19}$. W reakcji na zmianę prawa w Muzułmańskiej Gminie Wyznaniowej w Kruszynianach zaprzestano uboju rytualnego, mimo dezaprobaty dla wprowadzonego zakazu, natomiast w Muzułmańskiej Gminie Wyznaniowej w Bohonikach nie przestano dokonywać ubojów rytualnych, uznając tradycję religijną za ważniejszą. W związku z medialnym nagłośnieniem sprawy w Bohonikach w 2013 roku podczas święta Kurban Bajram odbył się, jak to określają Tatarzy, „najazd animalsów” i doszło do przepychanek oraz utarczek słownych przy wejściu na teren gminy wyznaniowej. Sytuacja stawała się coraz bardziej napięta. Z kolei w Kruszynianach o tym, by zaprzestać uboju, zdecydował Bronisław Talkowski, przewodniczący tamtejszej Muzułmańskiej Gminy Wyznaniowej, uzasadniając to następująco: „zrezygnowaliśmy z rytualnego uboju, żeby nie tworzyć zamieszania i żeby szanować prawo. Jesteśmy obywatelami tego państwa i uważamy, że prawo musi być przestrzegane. Ale nie zaprzestajemy działania, żeby władza państwowa przyzwoliła na możliwość uboju rytualnego [...] Chcemy żeby szanowano zasady naszej wiary"20. Dlatego też we wrześniu 2014 roku Tatarzy domagali się w sejmie podczas posiedzenia komisji mniejszości narodowych wprowadzenia rozwiązań umożliwiających ubój rytualny zwierząt podczas uroczystości religijnych. Wskazywano, że zakaz jest naruszeniem wolności religii i wyznania. Ostatecznie 10 grudnia 2014 roku Trybunał Konstytucyjny uchylił zakaz dokonywania uboju rytualnego bez ogłuszenia zwierzęcia,

19 Sprawa uboju rytualnego została nagłośniona w Polsce pod koniec 2012 roku, kiedy to Trybunał Konstytucyjny orzekł, że rozporządzenie ministra rolnictwa z 2004 roku dotyczące warunków uboju rytualnego zwierząt jest sprzeczne z ustawą o ochronie zwierząt z 21 sierpnia 1997 roku, której nowelizacja z 2002 roku nakazywała przeprowadzanie uboju tylko po uprzednim ogłuszeniu zwierząt, nie przewidując wyjątku dla uboju rytualnego. W związku z tym w 2013 i 2014 roku obowiązywał w Polsce całkowity zakaz uboju rytualnego bez ogłuszenia. Zob. A. Dziadzio, Zakaz uboju rytualnego jako naruszenie konstytucyjnej zasady wolności religijnej. Kontekst wspótczesny i historyczny, „Forum Prawnicze” 2014 nr 1, s. 7.

20 Materiał TVP3 Regionalnej w Białymstoku: http://www.tvp.pl/bialystok/publicystyka/rozmowa-dnia/wideo/bronislaw-talkowski-15102013/12708192?start_rec=24 [10.03.2016]. 
przyznając rację Tatarom. Sprawa uboju zmusiła Tatarów do zmierzenia się z dylematem, czy respektować prawo państwowe, czy kultywować wielowiekową tradycję religijną. Podczas badań wskazywano na wpływ chwilowego nagłośnienia sprawy w mediach na chwilową intensyfikację grup sprzeciwiających się ubojowi rytualnemu.

Z okresem przeprowadzania badań w Bohonikach i Kruszynianach pokryła się ekspansja tzw. Państwa Islamskiego, obfitująca w okrucieństwo i ludobójstwo pod sztandarami islamu i w imię Allaha. Nie dziwi zatem, że w swych wypowiedziach Tatarzy stanowczo odcinali się od Daesh. Typowymi zarejestrowanymi wypowiedziami były:

- „to nie islam, to terroryści [...] islam nie pozwala bić czy mordować w imię wiary";

- „żyli w kraju szatana, brali socjal i pojechali do raju, ale nie chcą w nim żyć”.

W wypowiedziach odnaleźć można również głos obawy przed wrzuceniem do jednego worka ze skrajnie radykalnymi wyznawcami islamu. Aktom terroru towarzyszyły bowiem niekiedy odwety skierowane przeciwko gminom wyznaniowym w Europie, mimo ich odcinania się od tzw. Państwa Islamskiego. Przejawiały się one najczęściej aktami wandalizmu w meczetach. Tak stało się również w Kruszynianach, gdzie na meczecie i grobach pobliskiego mizaru zostały namalowane obraźliwe rysunki. Tatarzy są przekonani, że uczynił to ktoś z zewnątrz, z pewnością nie mieszkaniec Kruszynian bądź którejś z okolicznych wsi.

Winę w rozprzestrzenieniu się tzw. Państwa Islamskiego dostrzegano również po stronie muzułmanów, którzy w porę nie zareagowali na „powstający twór"21. Tatarzy polscy wpisują się zatem w ogólny nurt potępiania terroru, przemocy i wszelkich barbarzyńskich działań tzw. Państwa Islamskiego, z jakim mamy do czynienia w całej Europie.

Z kolei stanowisko wobec narastającej fali uchodźców przemierzających Europę w ucieczce przed wojną w Syrii wraz z korzystającymi z okazji i dołączającymi do nich imigrantami ekonomicznymi określić można jako konkretne i stanowcze. Warto odnotować tu wypowiedź postulującą wnikliwą kontrolę przybywających imigrantów, jeżeli rząd zdecyduje się na ich przyjęcie. Podano również receptę na bezpieczne przyjęcie imigrantów:

21 „Tutaj sami muzułmanie też są sobie winni, bo jeżeli mamy do czynienia z pewnymi elementami bandyckimi, które się podszywają, podczepiają i tworzą jakiś twór pod nazwą Państwo Islamskie, do którego to państwo w ogóle nie aspiruje..." (ASC, Badania terenowe. BohonikiKruszyniany, 30.04-03.05.2015, mat. nr 2). 
- „Jeśli ma intencje szczere i chce tutaj coś wnosić w rozwój Polski, to proszę bardzo, a jak nie, to nie [...] Polska jest takim dziwnym krajem, że nigdy nie wyciąga wniosków na czas".

- „Ja bym był za tym, żeby podpisywali jakieś karty, że kiedy jest łamane prawo polskie, to takiego obywatela, któremu Polska dała gościnę, no niestety się deportuje zrazem z jego rodziną".

Sytuację imigrantów z Syrii porównano z podobnym położeniem Tatarów krymskich uciekających przed prześladowaniami z okupowanego przez Rosję Krymu. Im jednak Polska odmówiła schronienia. Większość z nich została zawrócona z granicy polsko-ukraińskiej z wytłumaczeniem, że nie cała Ukraina jest objęta wojną $\mathrm{i}$ jeśli chcą uciec $\mathrm{w}$ bezpieczne miejsce - mają je bliżej, na Ukrainie. Przyjętych kilkanaście rodzin Tatarów krymskich, które trafiły do Białegostoku, otrzymało pomoc od Gminy Muzułmańskiej i muftiego, niemniej jednak władze polskie nie chcą dać większości z nich nawet pobytu czasowego. Tatarzy polscy pomagają im się asymilować i radzą uczyć się języka polskiego. A więc i w tej sytuacji są propagatorami asymilacji.

\section{Podsumowanie}

Polscy Tatarzy stanowią specyficzną grupę etniczną, wyróżniającą się spośród innych brakiem własnego żywego języka, muzyki czy literatury oraz brakiem jakiejś starej, opuszczonej ojczyzny. Wpływa to na bardzo mocną więź z Polską i powszechne postawy patriotyczne oraz wysoki stopień asymilacji, jednak bez utraty odrębnych, charakterystycznych cech grupy. Wyznawany islam i wspólne pochodzenie to najważniejsze elementy tożsamości etnicznej Tatarów. Mimo pielęgnowania własnej kultury w Polsce, wielu Tatarów obawia się spadku liczby przedstawicieli tej mniejszości etnicznej, głównie na skutek stopniowego odchodzenia od religii i tradycji przy okazji zawierania związków małżeńskich z osobami spoza grupy oraz w wyniku emigracji. W obrębie małej grupy etnicznej trudno znaleźć małżonka, co może przyśpieszać proces jej dekonsolidacji. Z drugiej strony, można zauważyć również tendencję powrotów do swojej „małej ojczyzny”, do Bohonik i Kruszynian na Podlasiu, gdzie wielu Tatarów chce mieć swój, choćby sezonowy dom, a w stosunkowo dużym ruchu turystycznym upatrywane są perspektywy utrzymania się i osiedlenia.

Powstające w Kruszynianach Centrum Edukacji i Kultury Muzułmańskiej Tatarów Polskich należy uznać za działanie na rzecz zachowania i pielęgno- 
wania kultury tatarskiej. Jego twórcy rozumieją, że los Polaków tatarskiego pochodzenia spoczywa głównie w ich własnych rękach.

\section{Bibliografia}

\section{Źródła}

Archiwum Sławomira Cebuli (ASC), Badania terenowe. Bohoniki-Kruszyniany, 30.0403.05.2015, mat. nr 1-2.

Główny Urząd Statystyczny, Ludność. Stan i struktura demograficzno-społeczna. Narodowy Spis Powszechny Ludności i Mieszkań 2011, Warszawa 2013.

Polscy muzulmanie - rozmowa z Barbara Pawlic-Miśkiewicz przeprowadzona przez Tomka Kaczora i Jana Wiśniewskiego, „Kontakt” 2016 nr 31, s. 98-101.

Materiał TVP3 Regionalnej w Białymstoku: http://www.tvp.pl/bialystok/publicysty$\mathrm{ka} /$ rozmowa-dnia/wideo/bronislaw-talkowski-15102013/12708192? start_rec $=24$ [10.03.2016].

\section{Opracowania i artykuły}

Cicha K., Urwana nuta, „Kontakt” 2016 nr 31, s. 102-105.

Ciecieląg P., Wyznania religijne w Polsce 2012-2014, Warszawa 2016.

Dziadzio A., Zakaz uboju rytualnego jako naruszenie konstytucyjnej zasady wolności religijnej. Kontekst współczesny i historyczny, „Forum Prawnicze” 2014 nr 1, s. 6-13.

Kamocki J., Tatarzy polscy jako grupa etnograficzna, „Rocznik Tatarów Polskich” 1 (1993), s. 43-47.

Kulwicka-Kamińska J., Kamiński I., Islam po polsku, Poznań 2007.

Łyszczarz M., Młode pokolenia polskich Tatarów, Olsztyn-Białystok 2013.

Nowicka E., Dystans polskich katolików wobec innych wyznań, w: Religia a obcość, red. E. Nowicka, Kraków 1991, s. 26-55.

Rudy M., Rudy A., Mazur P., Ubój rytualny w prawie administracyjnym, Warszawa 2013.

Sztompka P., Socjologia, Kraków 2004.

Talko-Hryncewicz J., Muślimowie, czyli tak zwani Tatarzy Litewscy, Kraków 1924.

Warmińska K., Islam a etniczność na przykładzie Tatarów polskich, w: Miscellanea islamica. Islam $w$ badaniach i praktyce kontaktów międzykulturowych, red. P. Stawiński, Kraków 2016, s. 123-144.

Warmińska K., Religijność a dylematy tożsamości - Tatarzy polscy, w: Między Wschodem a Zachodem, red. P. Stawiński, Częstochowa 1995, s. 47-54.

Warmińska K., Tatarzy polscy - tożsamość religijna i etniczna, Kraków 1999. 